\title{
Reduced expression of the growth hormone and type 1 insulin-like growth factor receptors in human somatotroph tumours and an analysis of possible mutations of the growth hormone receptor
}

\begin{abstract}
Blerina Kola*, Márta Korbonits*, Salvador Diaz-Cano*, Gregory Kaltsas*, Damian G. Morris*, Suzanne Jordan*, Lou Metherell*, Michael Powellt, Sándor Czirjákł, Giorgio Arnaldi§, Stephen Bustinๆ, Marco Boscaro**, Franco Mantero** and Ashley B. Grossman*

*Departments of Endocrinology and Histopatholgy, St Bartholomew's Hospital and †National Institute of Neurology and Neurosurgery, London, UK, ¥Institute of Neurosurgery, Budapest, Hungary, §Division of Endocrinology, University of Ancona, Italy, $\mid$ Academic Department of Surgery, The Royal London Hospital, London, UK and ${ }^{* *}$ Department of Medical and Surgical Sciences, University of Padova, Italy
\end{abstract}

(Received 21 February 2003; returned for revision 23 February 2003; finally revised 23 April 2003; accepted 14 May 2003)

\section{Summary}

OBJECTIVE Clinical acromegaly is characterized by elevated GH secretion in the presence of high circulating IGF-I levels. We hypothesized that the physiological IGF-I/GH negative feedback loop may be reset in somatotroph adenomas, specifically in terms of the level of expression of these receptors or mutations of the $\mathrm{GH}$ receptor (GH-R) in such tumours.

METHODS We therefore investigated the full coding sequence of the GH-R in a series of somatotroph and other pituitary adenomas. We also investigated the mRNA expression of these putative feedback receptors in a series of pituitary adenomas and normal pituitary tissue, and their protein expression by immunostaining. Real-time RT-PCR assay was used for the quantification of the type 1 IGF receptor (IGF-R) and GH receptor (GH-R) mRNA, and sequence analysis was performed on the coding region of the GH-R gene. RESULTS No somatic mutations of the GH-R mRNA were detected in $18 \mathrm{GH}$-secreting tumours or two non-

Correspondence: Prof. A.B. Grossman, Endocrine Oncology, Department of Endocrinology St Bartholomew's Hospital, London, EC1A 7BE, UK. Tel: +44 207601 8343; Fax: +44 2076018505.

E-mail: A.B.Grossman@qmul.ac.uk functioning pituitary adenomas (NFPAs). However, the levels of GH-R mRNA were significantly lower in both somatotroph tumours and NFPAs compared to the normal pituitary $(P<0.05$ for both). Immunostaining for GH-R also showed significantly less GH-R expression in somatotroph adenomas compared to normal pituitary tissue $(P<0.0001)$. IGF-R mRNA levels were significantly lower in somatotroph tumours compared to normal pituitary $(P=0.005)$, and trended lower in corticotroph tumours $(P=0.07)$, while the other tumour types showed no significant difference from normal pituitary. Immunostaining for IGF-R also showed less IGF-R protein in the somatotroph adenomas compared to the normal pituitary tissue $(P<0.01)$.

CONCLUSIONS Our findings suggest that decreased feedback inhibition of GH because of somatic mutations of the coding region of the GH-R are unlikely to be a common factor in the pathogenesis of these tumours. Nevertheless, decreased expression of the GH-R and of IGF-R in somatotroph tumours (both at the mRNA and protein level) may, at least in part, help explain the continuous secretion of $\mathrm{GH}$ from the tumour despite the high circulating levels of IGF-I and GH.

Our understanding of the pathogenesis of pituitary tumours in general, and of somatotroph tumours in particular, has considerably increased in recent years, but the precise molecular mechanisms remain unclear (Asa \& Ezzat, 1998). One genetic abnormality seen in some $4-40 \%$ of human $\mathrm{GH}$-secreting adenomas is a somatic mutation of the $\alpha$-subunit of the G protein (GNASI gene; Landis et al., 1989). Some somatotroph adenomas occur in patients with Carney complex and are caused by a mutation in the type $1 \alpha$ regulatory subunit of PKA (PRKAR1A; Kirschner et al., 2000), but this has not been found in sporadic somatotroph adenomas (Kaltsas et al., 2002). The role of PTTG or the presence of a constitutively active truncated form of the FGF receptor type 4 (Ezzat et al., 2002) has also been intensively studied recently.

The regulation of $\mathrm{GH}$ secretion, and of somatotroph cell growth and proliferation, includes several hypothalamic factors such as growth hormone-releasing hormone (GHRH) (Barinaga 
et al., 1983; Billestrup et al., 1986), ghrelin (Bowers et al., 1984; Kojima et al., 1999; Hosoda et al., 2000) and somatostatin (Lamberts, 1988), but also involves feedback regulation by GH and IGF-I. IGF-I is the most important peripheral inhibitory factor regulating $\mathrm{GH}$ secretion, acting at both hypothalamic and direct pituitary levels to inhibit GH release (Berelowitz et al., 1981; Tannenbaum et al., 1983; Yamashita et al., 1986; Yamashita \& Melmed, 1987). There is also evidence for a paracrine/autocrine role of IGF-I on the pituitary. Binding sites for IGF-I and later the presence of mRNA coding for the type 1 IGF receptor (IGF$\mathrm{R})$ and its binding proteins were found throughout the anterior lobe of the rat pituitary (Goodyer et al., 1984). However, IGF-R mRNA is expressed by all the endocrine cells of the pituitary, not only by somatotrophs, suggesting that it may have a growth factor-related role in place of, or in addition to, any regulation of somatotroph secretion (Bach \& Bondy, 1992).

There is also considerable evidence that $\mathrm{GH}$ can regulate its own secretion via a negative feedback mechanism (Fagin et al., 1988; Pontiroli et al., 1991; Rosenthal et al., 1991; Lanzi \& Tannenbaum, 1992; Asa et al., 2000). Given either centrally or peripherally, GH causes a marked suppression of the spontaneous bursts of GH secretion in the male rat (Tannenbaum, 1980; Willoughby et al., 1980; Abe et al., 1983; Clark et al., 1988). In humans, GH pretreatment attenuates the $\mathrm{GH}$ response to various pharmacological (hypoglycaemia, arginine, clonidine or GHRH) or physiological (sleep, exercise) stimuli (Abrams et al., 1971; Hagen et al., 1972; Mendelson et al., 1983; Nakamoto et al., 1986; Ross et al., 1987a). These effects occur prior to the rise in circulating IGF-I levels, suggesting a direct role of GH per se. These effects are mediated, at least in part, by hypothalamic pathways, including the stimulated release of somatostatin (Ross et al., 1987b). However, there may be direct modulation of pituitary function: $\mathrm{GH}$ receptor (GH-R) mRNA is found ubiquitously distributed throughout the pituitary gland (Fraser \& Harvey, 1992; Harvey \& Fraser, 1992; Hull et al., 1992; Harvey et al., 1993), and GH is also involved in the synthesis and regulation of pituitary IGF-I (Fagin et al., 1988, 1989). GH might therefore act directly as a regulator of GH synthesis and secretion (Ezzat \& Melmed, 1990; Mertani et al., 1994).

Acromegaly is characterized by alterations in the physiological negative feedback regulation of GH and IGF-I on their own secretion, with coexistent elevations in both GH and IGF-I simultaneously. We have therefore speculated that the physiological IGF-I/GH negative feedback loop may be altered or set to a higher point in this disease as a consequence of either qualitative or quantitative changes in GH-R and IGF-R expression. The aim of this study was to investigate the possible presence of GH-R mutations in somatotroph tumours, and to quantify and compare the level of expression of the GH-R and IGF-R mRNA in somatotroph tumours compared to other pituitary tumours and to normal pituitary tissue.

\section{Materials and methods}

\section{Tumour specimens}

Fifty-eight human pituitary adenomas, $25 \mathrm{GH}$-secreting tumours, 21 nonfunctioning pituitary adenomas (NFPAs), five ACTHsecreting tumours, four prolactin-secreting tumours and three FSH-secreting tumours were obtained at the time of transsphenoidal surgery (Table 1 ). Tumours were collected in liquid nitrogen and then stored at $-80^{\circ} \mathrm{C}$. The tumour type was determined on the basis of clinical and biochemical findings before surgery, and by morphological and immunocytochemical data of the removed tissue sample. Normal human pituitary autopsy specimens (six samples), obtained within $24 \mathrm{~h}$ of death, were obtained from patients with no evidence of any endocrine abnormality. Informed consent was obtained from all patients, and the study was approved by the local Ethics Committee.

\section{RNA preparation}

Total RNA was prepared using the Promega SV isolation kit (Promega, Southampton, UK), which includes a DNase step. RNA was quantified by spectrophotometry (Cecil CE Computing Double Beam UV Spectrophotometer, Cecil Instruments Ltd, Cambridge, UK) and by using RiboGreen ${ }^{\mathrm{TM}}$ RNA Quantification Reagent Kit (Molecular Probes Europe BV, Leiden, the Netherlands) in a 1420 Multilabel Counter Wallac Victor 2. RNA was diluted to $50 \mathrm{ng} / \mu \mathrm{l}$ for use in the RT-PCR assay and stored at $-80^{\circ} \mathrm{C}$.

\section{Primers and probes}

Real-time RT-PCR primers and probes for GH-R and IGF-R (Table 2) were designed using Primer Express software [PEApplied Biosystems (PE-ABI), Warrington, UK] based on the published sequence data of the two genes (GH-R: NM_000163, IGF-R: NM_000875). The TaqMan ${ }^{\mathrm{TM}}$ probes were labelled with a reporter dye (6-carboxy-fluorescein, FAM) at the $5^{\prime}$ end and a quencher dye (6-carboxy-tetramethylrodamine, TAMRA) at the $3^{\prime}$ end. Seven sets of primers were designed for amplifying and sequencing the whole coding region of the GH-R mRNA (Table 3).

\section{$R T$ and $P C R$ for sequencing}

Total RNA was reverse-transcribed into complementary DNA (cDNA) using standard procedures as described before (Korbonits et al., 2001). PCR reactions run with a control tube containing the PCR reaction mixture but instead of cDNA, water as a template. For a $50-\mu 1$ reaction, we used $5 \mu 1$ of cDNA, deoxynucleotides at $200 \mu \mathrm{M}$ concentration, primers at $1 \mu \mathrm{M}$ concentration, $\mathrm{MgCl}_{2}$ at $1.5 \mathrm{~mm}$ concentration and $0.125 \mathrm{U}$ Taq (Promega) according to the manufacturers' guidelines. Forty cycles were 
Table 1 Clinical characteristics of the patients

\begin{tabular}{|c|c|c|c|c|c|}
\hline Sample no. & Diagnosis & Age (years) & Sex & Size of tumor & Immunohistochemistry \\
\hline 1 & Acromegaly & 35 & M & Macro & $\mathrm{GH}, \alpha \mathrm{SU}$ \\
\hline 2 & Acromegaly & 53 & M & Macro & GH \\
\hline 3 & Acromegaly & 26 & $\mathrm{M}$ & Macro & LH, FSH, TSH, GH, PRL \\
\hline 4 & Acromegaly & 29 & $\mathrm{~F}$ & Macro & $\mathrm{GH}$ \\
\hline 5 & Acromegaly & 44 & $\mathrm{M}$ & Macro & GH, PRL, TSH \\
\hline 6 & Acromegaly & 22 & $\mathrm{M}$ & Macro with SSE & $\mathrm{GH}, \alpha \mathrm{SU}$ \\
\hline 7 & Acromegaly & 60 & $\mathrm{M}$ & Macro & GH \\
\hline 8 & Acromegaly & 50 & $\mathrm{M}$ & Macro & GH, PRL \\
\hline 9 & Acromegaly & 61 & M & Macro with SSE & GH \\
\hline 10 & Acromegaly & 47 & M & Macro with SSE & GH \\
\hline 11 & Acromegaly & 35 & $\mathrm{M}$ & Macro with SSE & GH \\
\hline 12 & Acromegaly & 41 & M & Micro & GH \\
\hline 13 & Acromegaly & 69 & M & Macro & GH \\
\hline 14 & Acromegaly & NA & $\mathrm{F}$ & Macro & GH \\
\hline 15 & Acromegaly & 28 & $\mathrm{~F}$ & Macro & GH \\
\hline 16 & Acromegaly & 66 & $\mathrm{M}$ & Micro & GH \\
\hline 17 & Acromegaly & 44 & $\mathrm{M}$ & Macro & GH \\
\hline 18 & Acromegaly & 66 & $\mathrm{M}$ & Macro & GH \\
\hline 19 & Acromegaly & 44 & $\mathrm{~F}$ & Macro & GH \\
\hline 20 & Acromegaly & 48 & M & Macro & GH \\
\hline 21 & Acromegaly & 52 & $\mathrm{~F}$ & Macro & GH \\
\hline 22 & Acromegaly & 30 & $\mathrm{M}$ & Macro with SSE & GH, PRL \\
\hline 23 & Acromegaly & 65 & $\mathrm{~F}$ & Micro & $\mathrm{GH}$ \\
\hline 24 & Acromegaly & 44 & $\mathrm{~F}$ & Macro & GH \\
\hline 25 & Acromegaly & 30 & $\mathrm{~F}$ & Macro & GH, PRL \\
\hline 26 & Cushing's & 53 & $\mathrm{~F}$ & Micro & ACTH \\
\hline 27 & Cushing's & 28 & $\mathrm{~F}$ & Micro & АCTH \\
\hline 28 & Cushing's & NA & $\mathrm{F}$ & NA & ACTH \\
\hline 29 & Cushing's & 66 & $\mathrm{~F}$ & Micro & ACTH \\
\hline 30 & Cushing's & 25 & $\mathrm{~F}$ & Micro & ACTH \\
\hline 31 & FSHoma & 48 & $\mathrm{M}$ & Macro & FSH \\
\hline 32 & FSHoma & 59 & M & Macro & FSH \\
\hline 33 & FSHoma & 16 & $\mathrm{M}$ & Macro & FSH $, \alpha \mathrm{SU}, \alpha \mathrm{HCG}$ \\
\hline 34 & NFPA & 59 & $\mathrm{M}$ & Macro & all neg \\
\hline 35 & NFPA & 38 & $\mathrm{M}$ & NA & NA \\
\hline 36 & NFPA & 80 & $\mathrm{~F}$ & Macro with SSE & $\alpha \mathrm{SU}$ \\
\hline 37 & NFPA & 82 & $\mathrm{M}$ & Macro & all neg \\
\hline 38 & NFPA & 68 & $\mathrm{M}$ & Macro with SSE & all neg \\
\hline 39 & NFPA & 41 & M & Macro with SSE & all neg \\
\hline 40 & NFPA & 66 & $\mathrm{~F}$ & Macro & LH, $\alpha \mathrm{HCG}$ \\
\hline 41 & NFPA & 53 & $\mathrm{~F}$ & Macro with SSE & all neg \\
\hline 42 & NFPA & 50 & $\mathrm{~F}$ & Micro & all neg \\
\hline 43 & NFPA & 61 & $\mathrm{M}$ & NA & all neg \\
\hline 44 & NFPA & 72 & $\mathrm{~F}$ & Macro & all neg \\
\hline 45 & NFPA & 58 & $\mathrm{M}$ & NA & all neg \\
\hline 46 & NFPA & 59 & $\mathrm{M}$ & Macro with SSE & FSH \\
\hline 47 & NFPA & 68 & $\mathrm{M}$ & NA & all neg \\
\hline 48 & NFPA & 65 & $\mathrm{M}$ & NA & all neg \\
\hline 49 & NFPA & 45 & M & Macro & all neg \\
\hline 50 & NFPA & 55 & $\mathrm{M}$ & NA & all neg \\
\hline 51 & NFPA & 61 & $\mathrm{~F}$ & Macro & all neg \\
\hline 52 & NFPA & 60 & $\mathrm{~F}$ & Macro & all neg \\
\hline 53 & NFPA & 50 & $\mathrm{M}$ & Macro & all neg \\
\hline 54 & NFPA & 51 & $\mathrm{M}$ & Macro & all neg \\
\hline 55 & PRLoma & 30 & $\mathrm{~F}$ & Macro & PRL \\
\hline 56 & PRLoma & 36 & M & Macro & PRL, TSH, GH \\
\hline 57 & PRLoma & NA & M & Macro & PRL \\
\hline 58 & PRLoma & 29 & $\mathrm{~F}$ & Macro & PRL \\
\hline 59 & Normal pituitary & NA & NA & NA & NA \\
\hline 60 & Normal pituitary & NA & NA & NA & NA \\
\hline 61 & Normal pituitary & NA & NA & NA & NA \\
\hline 62 & Normal pituitary & NA & NA & NA & NA \\
\hline 63 & Normal pituitary & NA & NA & NA & NA \\
\hline 64 & Normal pituitary & NA & NA & NA & NA \\
\hline
\end{tabular}

$\alpha \mathrm{SU}, \alpha$-subunit; Macro $>10 \mathrm{~mm}, \mathrm{SSE}$, suprasellar extension; NA, not available. 
Table 2 Primers and probes for GH-R and IGF-R for real-time RT-PCR

\begin{tabular}{llll}
\hline Gene & Forward primer & Reverse primer & TaqMan probe \\
\hline GH-R & TTTGGAATATTTGG & TCACCTCCTCTAATTTT & AAGGATTAAAATGCTG \\
& GCTAACAGTG & CCTTCCTT & ATTCTGCCCCCAGT \\
IGF-R & CTCCTGTTTCTCTC & ATAGTCGTTGCGGATGT & $\begin{array}{l}\text { TGGCCCGCAGATTTCTC } \\
\end{array}$ \\
CGCCG & CGAT & CACTCGT \\
\hline
\end{tabular}

Table 3 GH-R gene primers for conventional PCR and sequencing (base-pair numbers refer to NM_000163)

\begin{tabular}{llc}
\hline Primer & Primer sequence & Base-pairs \\
\hline F1 & GCTCGGAGGTCCTACAGGTAT & $25-518$ \\
R1 & CATTGCCCTCAACTGGACTT & \\
F2 & GCCACTGGACAGATGAGGTT & $240-741$ \\
R2 & GAAGTGCGTGTGAGATCCAA & \\
F3 & AGTGAGATGGGAAGCACCAC & $559-1059$ \\
R3 & AAACCCGAATTCCACAGTGA & \\
F4 & GAAGTGCGTGTGAGATCCAA & $722-1208$ \\
R4 & CGACTCTGGACGTACCAGCT & \\
F5 & CAAAGATTAAAGGAATCGATCCAG & $954-1462$ \\
R5 & CTCACCAAGCTGCCCATATT & \\
F6 & AACCTAGGGGTGAAGGATGG & $1169-1676$ \\
R6 & AGATGCCAAAAAGTGCATCC & \\
F8 & CCAGCAGGTAGTGTGGTCCT & $1526-2025$ \\
R8 & TGACTGGGGCAATAACGTTT & \\
\hline
\end{tabular}

performed at $95^{\circ} \mathrm{C}$ for $30 \mathrm{~s}, 60^{\circ} \mathrm{C}$ for $30 \mathrm{~s}$ and $72^{\circ} \mathrm{C}$ for $1 \mathrm{~min}$, after a first denaturing cycle at $95^{\circ} \mathrm{C}$ for $5 \mathrm{~min}$. A final extension cycle of $10 \mathrm{~min}$ at $72^{\circ} \mathrm{C}$ was used. PCR products were run on $2 \%$ ethidium bromide-stained agarose gels.

\section{Sequencing}

Direct sequencing was performed for the GH-R gene on 18 somatotroph tumours and two NFPAs as follows: PCR products were purified by using a QIAquick PCR purification kit protocol (Qiagen, Crawley, West Sussex, UK) or by using ExoSAP-IT kit protocol (USB Corporation, Cleveland, Ohio, USA). A 10- $\mu$ l cycle sequencing reaction was prepared by using $5 \cdot 5 \mu 1$ of the purified PCR product, $4 \mu \mathrm{l}$ of Terminator Ready Reaction Mix (ABI PRISM BigDye ${ }^{\mathrm{TM}}$ Terminator version $2 \cdot 0, \mathrm{PE}-\mathrm{ABI}$ ) and $0 \cdot 5 \mu \mathrm{l}$ of the primer. Each PCR product was sequenced in both the forward and the reverse direction. The same set of primers used for the PCR amplification was used in this case as well. The cycle sequencing was performed on the GeneAmp 9700 with 25 cycles at $96^{\circ} \mathrm{C}$ for $10 \mathrm{~s}, 50^{\circ} \mathrm{C}$ for $5 \mathrm{~s}$ and $60^{\circ} \mathrm{C}$ for 4 min a rapid thermal ramp was used each time. The extensions products were consequently purified in order to remove the excess of dye terminators, which can interfere with base calling. This step was performed either by ethanol precipitation or by using Sephadex column precipitation plates (Amersham Life Science Ltd, Buckinghamshire, UK). Electrophoresis of the samples was performed on the ABI Prism 3700 DNA Analyser (PE-ABI). The samples were resuspended in $6 \mu 1$ of formaldehyde before being loaded into the analyser. The obtained sequences were compared to the published GH-R sequence.

\section{Determination of the 'gsp' status}

The 18 somatotroph adenomas, which were sequenced for GH$\mathrm{R}$, were also tested for the gsp mutations of the $\alpha$-subunit of the G protein (codons 201 and 227). The oligonucleotides used for amplification were 2F: ACCATTGTGAAGCAGATGAGGAT and 10R: CACGAAGATGATGGCAGTCAC (Hayward et al., 2001 ). For a $25-\mu 1$ reaction, we used $2.5 \mu 1$ of cDNA, deoxynucleotides at $200 \mu \mathrm{M}$ concentration, primers at $0.4 \mu \mathrm{M}$ concentration, $\mathrm{MgCl}_{2}$ at $1.5 \mathrm{~mm}$ concentration and $0.125 \mathrm{U}$ Taq polymerase. Thirty cycles were performed at $94^{\circ} \mathrm{C}$ for $30 \mathrm{~s}, 60^{\circ} \mathrm{C}$ for $30 \mathrm{~s}$ and $72^{\circ} \mathrm{C}$ for $30 \mathrm{~s}$, after a first denaturing cycle at $94^{\circ} \mathrm{C}$ for $5 \mathrm{~min}$. A final extension cycle of $7 \mathrm{~min}$ at $72^{\circ} \mathrm{C}$ was used. Direct sequencing was performed in both directions using primers 7F: CCTGGACAAGATCGACGTGA and 10R: CACGAAGATGATGGCAGTCAC and the same protocol as described above for the GH-R gene.

\section{Real-time PCR}

The RT-PCR reactions were performed, recorded, and analysed by using the ABI PRISM 7700 Sequence Detection system (PE$\mathrm{ABI}$ ). Absolute mRNA copy numbers were determined from a standard curve, which was obtained by serially diluting single stranded sense oligodeoxynucleotides, GH-R and IGF-R specific amplicons. A strong linear relationship between the threshold cycle $(\mathrm{Ct})$ and the log of the starting RNA-copy number was always found $(r=0 \cdot 99)$. Absolute mRNA levels are expressed as mRNA copy numbers $/ \mu \mathrm{g}$ total RNA (Bustin, 2000). There are conflicting data regarding the best method of RNA expression with some authors suggesting the use of housekeeping genes while others advocate the use of absolute RNA quantification. In the current study we have followed the latter possibility, particularly as we have shown earlier the unreliable nature of the former approach (Tricarico et al., 2002). Real-time RT-PCR were performed in duplicate as previously described (Bustin, 2000) using TaqMan ${ }^{\mathrm{TM}}$ 
EZ RT-PCR kit (PE-ABI). Briefly, the RT-PCR reaction was carried out in a $25-\mu 1$ reaction mixture containing $1 \times$ TaqMan EZ buffer, $3 \mathrm{~mm} \mathrm{Mn(Oac)2,} 300 \mathrm{~mm} \mathrm{dA} / \mathrm{dC} / \mathrm{dG} / \mathrm{dUTP}, 2.5 \mathrm{U}$ rTth DNA polymerase, 10 pmol primers, 5 pmol TaqMan ${ }^{\mathrm{TM}}$ probe, $0.5 \mathrm{U}$ AmpErase UNG and $100 \mathrm{ng}$ of total RNA at $50^{\circ} \mathrm{C}$ for $2 \mathrm{~min}, 60^{\circ} \mathrm{C}$ for $30 \mathrm{~min}, 92^{\circ} \mathrm{C}$ for $5 \mathrm{~min}$ followed by 40 cycles of PCR at $92^{\circ} \mathrm{C}$ for $20 \mathrm{~s}$ and $62^{\circ} \mathrm{C}$ for $1 \mathrm{~min}$.

\section{Immunostaining}

A sample of six somatotroph tumours and five samples of normal pituitary were subjected to immunocytochemical staining with antibodies to the GH-R and the IGF-R according to standard techniques. The normal pituitary was collected at transsphenoidal surgery from patients thought to harbour tumours but in whom no tumour was identified: we have previously found that such tissue provides a good control for tumour specimens, and by being collected in exactly the same manner as the pituitary tumour tissue does not suffer from problems with postmortem degradation seen with autopsy material (Lidhar et al., 1999; Korbonits et al., 2002). In brief, the tissue was collected into 4\% formalin and processed for paraffin embedding and avidinbiotin-peroxidase staining (Mertani et al., 1995). The GH-R antibody was the murine monoclonal $\mathrm{mAb} 263$, raised against the extracellular domain of the GH-R and supplied by Agen (Brisbane, Australia). The specific lot designation was D7·18·3D5/131. This was used at a final dilution of $1: 100$, and without pretreatment. Control slides with the addition of nonspecific immune serum were run to control for nonspecific staining. The IGF-R antibody (Santa Cruz Biotechnology, Santa Cruz, CA, USA; product number SC-712) was used in a similar manner at a dilution of $1: 50$. Slides were assessed by a histopathologist and the extension of the immunostaining was morphometrically evaluated blind in 10 high-power fields, counting positively stained cells according to a 100-point graticule. The results were expressed as the percentage of positive tumour cells. Standard western blotting was attempted for both antibodies, but neither demonstrated a band of the requisite size under a variety of different conditions (data not shown). It is well known that it is difficult to generate antibodies to the extra-cellular domain of cytokine receptors, and our results are compatible with data from the originators of the GH-R antibody (M. J. Waters, personal communication).

Photographs of slides were taken using a Leica Corporation DMR microscope and a Leica Corporation DC200 digital camera at a magnification of $\times 630$, and printed by an Epson 880 Stylus Color printer on HP PremiumPhoto paper.

\section{Statistical analysis}

Comparisons between mRNA expression of normal pituitary and each type of tumour were carried out with a nonparametric analysis of variance test, the Kruskal-Wallis test followed by the Dwass-Steel-Chritchlow-Fligner multiple comparison test (StatsDirect, I. Buchan, Addison Wesley Longman Ltd. Cambridge, UK). Spearman's rank order correlation tests were performed to see whether there was any correlation between GH-R mRNA level/IGF-R mRNA level and size of tumour or GH and IGF-I levels. Immunostaining data were calculated using the unpaired student's $t$-test as these data were normally distributed. Significance was taken at $P<0 \cdot 05$.

\section{Results}

GH-R mRNA was detected and quantified by using real-time RT-PCR in the following pituitary tumours: $25 \mathrm{GH}$-secreting tumours, 21 NFPAs, five ACTH-secreting tumours, four prolactin-secreting tumours and three FSH-secreting tumours, and in six autopsy normal pituitary samples. The level of GH-R mRNA expressed as median copy number/ $\mu$ g RNA was: somatotroph tumours $1.47 \times 10^{5}$, ACTH-secreting tumours $7 \cdot 10 \times 10^{4}$, FSHomas $3.06 \times 10^{5}$, NFPAs $1.50 \times 10^{5}$, PRLomas $2.50 \times 10^{5}$ and normal pituitary $1.31 \times 10^{6}$. The levels of GH-R mRNA were significantly lower in somatotroph tumours compared to normal pituitary $(P=0 \cdot 013)$, and NFPAs also showed significantly lower GH-R mRNA expression compared to normal pituitary $(P=0.0292$; Fig. 1$)$. There was no difference in GH-R mRNA levels between micro- and macroadenomas.

The presence of GH-R protein was identified by immunohistochemistry using a specific human GH-R antibody; the staining was blocked when the antibody was replaced by a nonimmune serum (Fig. 2). Somatotroph tumours showed significantly less GH-R immunostaining compared to normal pituitaries (11.7 \pm $0 \cdot 8$ vs. $30 \cdot 4 \pm 1 \cdot 1 \% ; P<0 \cdot 0001$, Fig. 3a).

IGF-R mRNA was detected and quantified by using real-time RT-PCR. The level of IGF-R mRNA expressed as median copy number/ $\mu$ g RNA was: somatotroph tumours $3.86 \times 10^{6}$, ACTHsecreting tumours $2.34 \times 10^{6}$, FSHomas $8.30 \times 10^{7}$, NFPAs

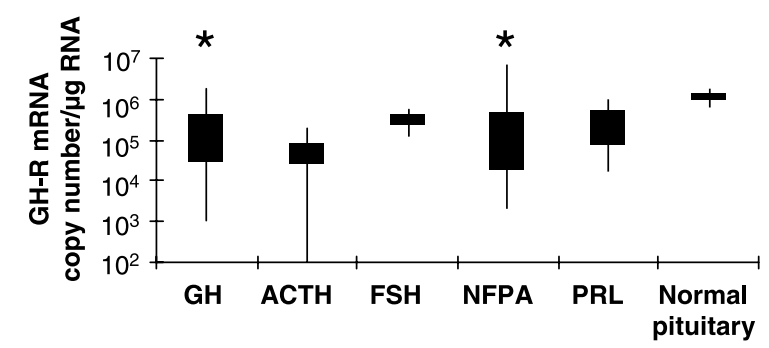

Fig. 1 GH-R mRNA expression in pituitary tumours (GH = somatotroph adenoma, $n=25$; NFPA $=$ nonfunctioning pituitary adenoma, $n=21$; ACTH $=$ corticotrophinoma, $n=5$; FSH $=\mathrm{FSH}-$ secreting tumour, $n=3$; PRL = prolactinoma, $n=4 ; \mathrm{NP}=$ normal pituitary, $n=6$ ). Inter-quartile ranges, maxima and minima are shown. $* P<0.05$ vs. normal pituitary. 


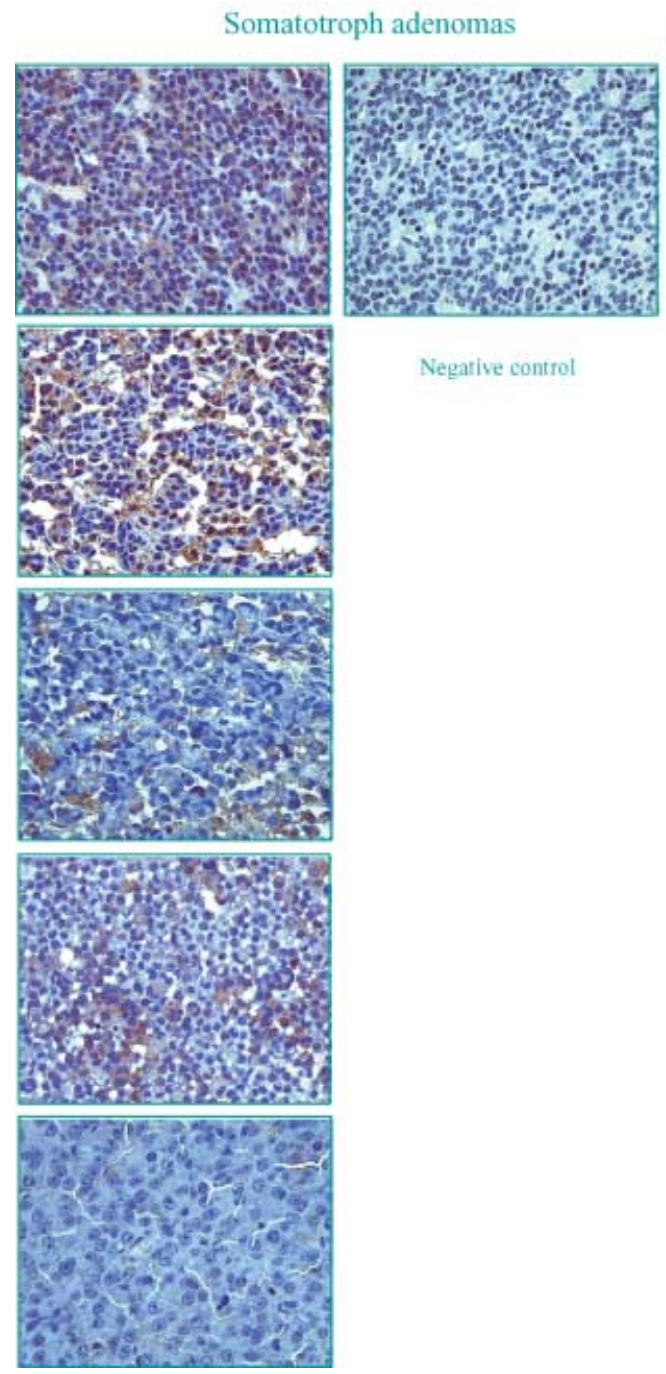

GH-R staining

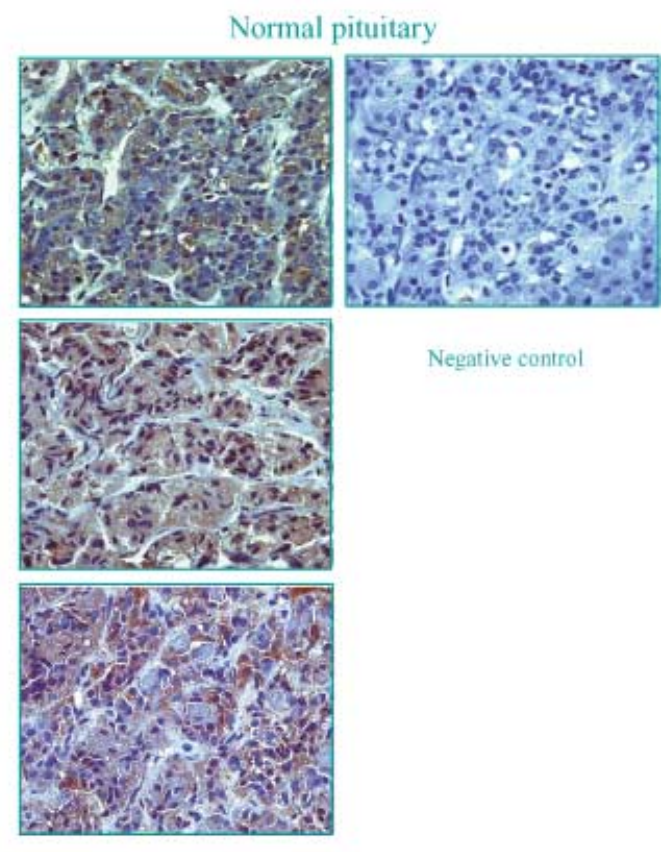

Fig. 2 A series of five somatotroph tumours (left panel) and three normal pituitaries (right panel) immunostained for GH-R. One somatotroph tumour and one normal pituitary show tissue sections where the GH-R antibody was replaced by nonspecific immune serum ('negative control'). All photomicrographs are shown at a magnification of $\times 630$.

$7 \cdot 97 \times 10^{7}$, PRLomas $5 \cdot 7 \times 10^{7}$ and normal pituitary $4 \cdot 42 \times 10^{7}$. IGF-R mRNA levels were significantly lower in somatotroph tumours compared to normal pituitary $(P=0.005)$, while the other tumour types showed no significant difference from normal pituitary, although there was a trend $(P=0 \cdot 07)$ for the corticotroph tumours to also express less IGF-R (Fig. 4). There was no difference in IGF-R mRNA levels between micro- and macroadenomas. IGF-R immunostaining showed significantly less positive cells in somatotroph adenomas than in normal pituitary tissue $(15 \cdot 7 \pm 1 \cdot 4$ vs. $29 \cdot 9 \pm 2 \cdot 1 \% ; P<0 \cdot 01$, Figs $3 \mathrm{~b}$ and 5$)$.

Direct sequencing of the coding region of (60-1960 bp) of the GH-R was performed in $18 \mathrm{GH}$-secreting tumours and two NFPAs. No alterations of the GH-R mRNA sequence were detected in the samples apart from four different and known polymorphisms of the GH-R gene (Table 4 and NCBI SNP Database; Edens \& Talamantes, 1998). Mutations of the Gs $\alpha$ gene were identified in $4 / 18$ samples, three samples with the R201C mutation and one sample with the Q227R mutation; there was no correlation with GH-R or IGF-R status and the gsp status of the adenomas.

\section{Discussion}

This study showed that GH-R and IGF-R are expressed in both normal and adenomatous human pituitary tissue. We used realtime RT-PCR to detect and quantify GH-R and IGF-R levels. 
(a)

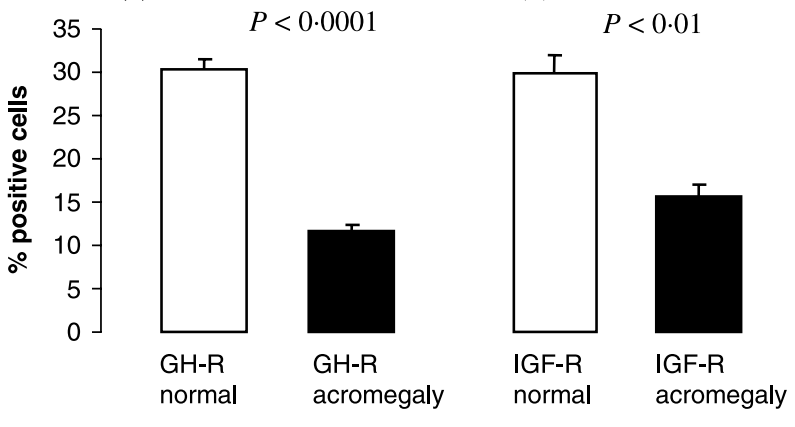

Fig. 3 Immunostaining results for GH-R (a) and IGF-R (b). Percentage of positive cells of 1000 cells counted in 10 high power fields were compared between normal pituitary tissue and somatotroph adenomas using the unpaired Student's $t$-test. Data are shown as mean \pm SEM.

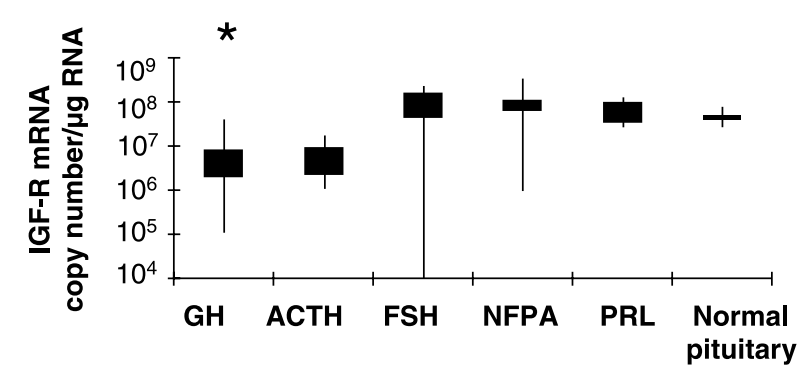

Fig. 4 IGF-R mRNA expression in pituitary tumours. (GH = somatotroph adenoma, $n=25$; NFPA $=$ nonfunctioning pituitary adenoma, $n=21$; ACTH = corticotrophinoma, $n=5$; FSH $=$ FSHsecreting tumour, $n=3$; PRL = prolactinoma, $n=4$; $\mathrm{NP}=$ normal pituitary, $n=6$ ). Inter-quartile ranges, maxima and minima are shown. $* P<0.05$ vs. normal pituitary.

All the samples, normal pituitaries and tumours arising from somatotroph, corticotroph, lactotroph and gonadotroph cells, as well as nonfunctioning adenomas, expressed both the GH-R and IGF-R. The level of GH-R mRNA was significantly lower in somatotroph tumours compared to normal pituitary; NFPA also showed lower GH-R mRNA expression while the other adenoma types were not significantly different to normals. We demonstrated that IGF-R mRNA levels were also significantly lower in somatotroph (and possibly corticotroph) tumours compared to normal pituitary. For the RNA studies we used autopsy normal pituitaries. In these samples a higher degree of RNA degradation and therefore lower level of specific RNA expression might be expected, while we found a higher level of GH-R RNA expression, suggesting that the use of autopsy tissue would not be likely to cause these results. Our immunostaining data suggest that the reduced expression of mRNA for both the GH-R and IGF-R in somatotroph tumours is also reflected in lower protein expression. In some of the tumour samples normal tissue was present adjacent to adenoma tissue, and the obvious difference of protein staining was clearly demonstrated in these slides as well.

The sequence analysis of the coding region of the GH-R gene did not reveal any abnormalities in $18 \mathrm{GH}$-secreting tumours. The relatively low frequency of gsp mutations in our population might be explained by the mixed ethnic background of our patients, as certain racial groups have a lower level of gsp mutations than patients of European origin (Harris, 1996).

Defects in the hormonal regulatory pathways are attractive candidates for causal factors in pituitary pathogenesis (Ezzat, 2001). Increased secretion of GH/IGF-I would suppress the surrounding normal somatotrophs, and the clonal expansion could re-establish feedback at a higher reset level. In favour of this is the report that showed that the negative feedback exerted by IGF-I on GH secretion is retained, but is markedly attenuated (Jaffe et al., 2001). However, somatic activating mutations of the GHRH-R (Salvatori et al., 2001) and ghrelin receptors (Petersenn et al., 2001) have not been identified in somatotroph tumours, and neither have inactivating mutations of the principal somatotroph somatostatin receptor, SSTR-2 (Petersenn et al., 2000). GH-R-deficient mice demonstrate mild somatotroph hyperplasia (an increase in proliferating cell nuclear antigen of 10 $14 \%$ ), disruption of the reticular fibre network and the presence of sparsely granulated cells, typical of pituitary GH-producing adenomas, suggesting a direct GH inhibitory feedback on the pituitary (Asa et al., 2000). There is also evidence for a ubiquitous distribution of the GH-R throughout the pituitary gland. GH-R mRNA and GH binding protein mRNA have been located in the cytoplasm and in the nucleus of somatotroph, lactotroph and gonadotroph rat pituitary cells (Mertani et al., 1994, 1995; Mertani $\&$ Morel, 1995). We have now carefully looked for mutations of the coding region of the GH-R, but found no somatic mutations in the coding regions of any of 18 somatotroph tumours or two NFPAs. This suggests that an abnormal form of the GH-R is unlikely to be causal in somatotroph pathogenesis. However, we did note that the GH-R is expressed by normal pituitary tissue, as well as in all the adenomas assessed. It is currently unclear as to the precise cell types which express the GH-R, but studies on GH feedback suggest that it is functionally present on at least the somatotrophs. Immunocytochemical staining indicates that the GH-R may also be expressed in lactotrophs and gonadotrophs, but is absent from corticotrophs and thyrotrophs (Mertani et al., 1995). Because the somatotrophs constitute some $50 \%$ of the total normal pituitary population, the four-fold lower expression in somatotroph tumours is highly suggestive that GH-R mRNA is indeed underexpressed by individual somatotroph adenoma cells.

We attempted to demonstrate the presence of GH-R protein in our samples. Western blotting proved to be unsuccessful due to lack of suitable antibody against the extracellular part of the GH-R. However, immunostaining demonstrated the presence of 
Somatotroph adenomas
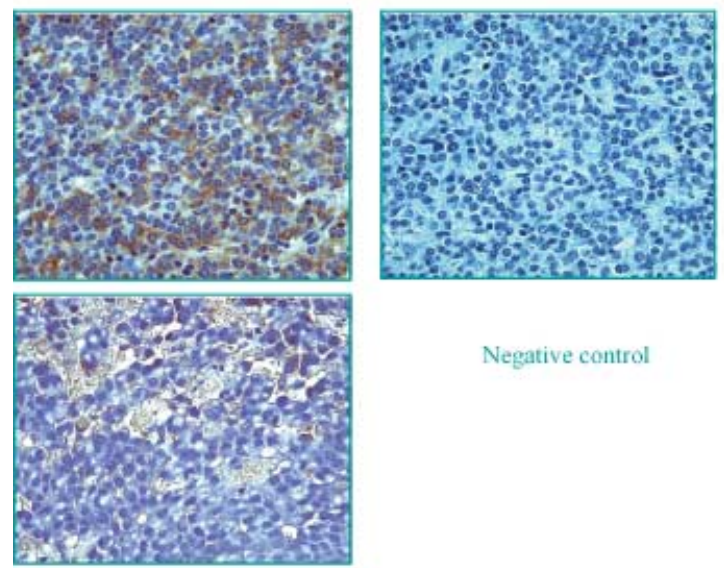

Negative control
IGR staining

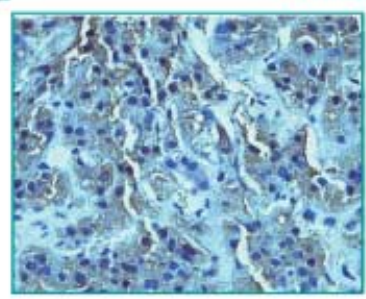

Normal pituitary
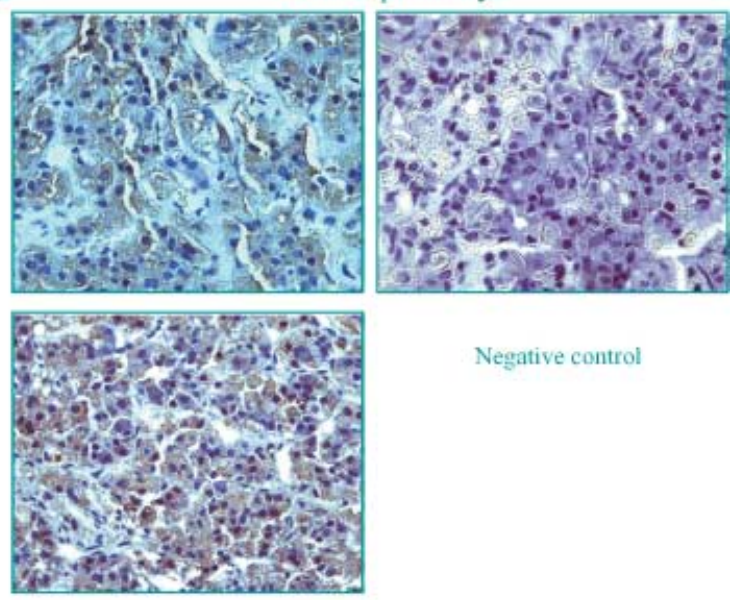

Negative control
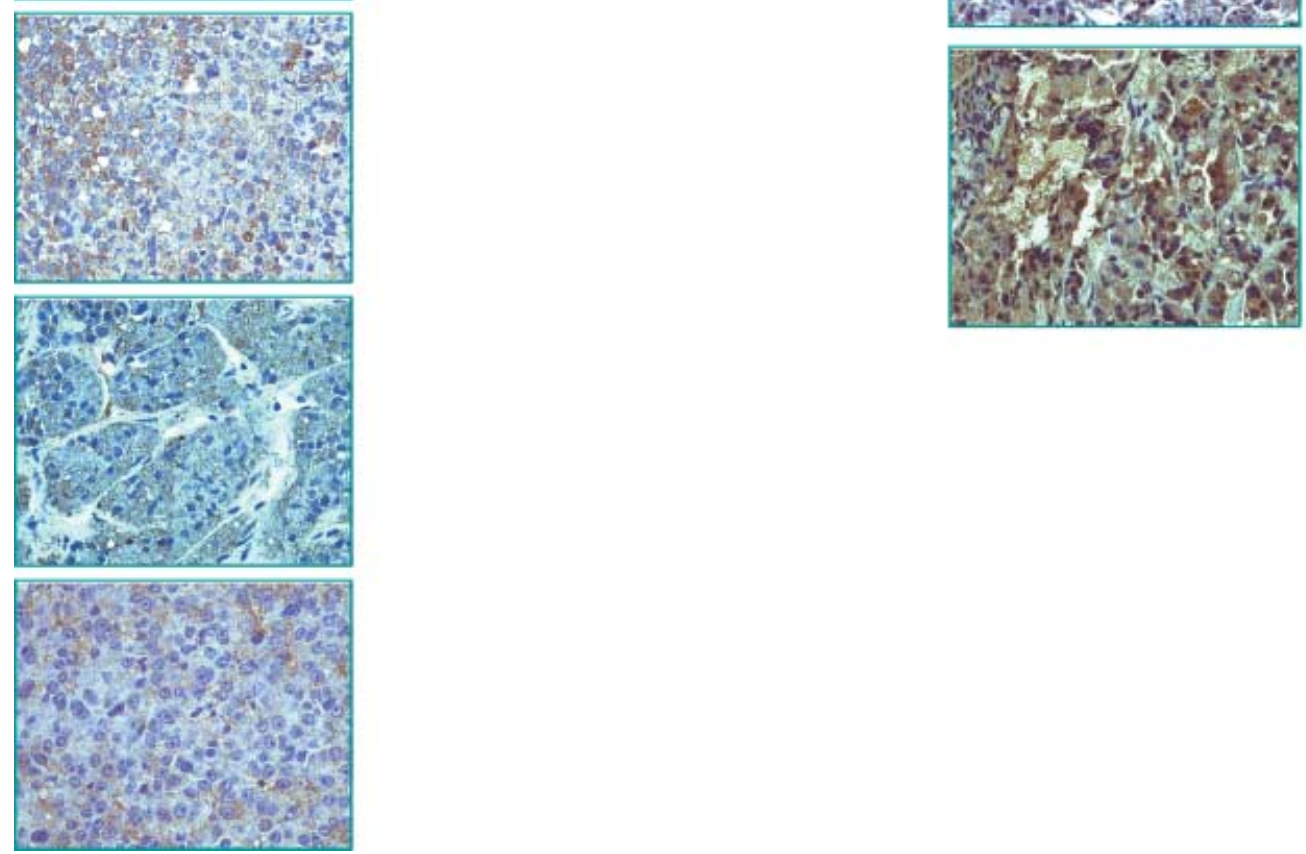

Fig. 5 A series of five somatotroph tumours (left panel) and three normal pituitaries (right panel) immunostained for IGF-R. One somatotroph tumour and one normal pituitary show tissue sections where the IGF-R antibody was replaced by nonspecific immune serum ('negative control'). All photomicrographs are shown at a magnification of $\times 630$.

the GH-R in many cells of the normal pituitary, compatible with a previous report using the same antibody (Mertani et al., 1995). In quantitative terms, the staining was significantly less than in the small series of somatotroph tumours stained in an identical manner and at the same time. Our results suggest that the decrease in GH-R mRNA is paralleled by a fall in receptor protein expression in somatotroph tumours.

Our results also showed a lower expression of IGF-R mRNA in somatotroph tumours compared to normal pituitary tissue. There is one previous report of a relatively low expression of
IGF-R mRNA in a small number of pituitary GH-producing adenomas, quantified by competitive RT-PCR reactions (Otsuka et al., 1999). We also noted that the normal pituitaries showed cytoplasmic staining for the IGF-R which was significantly decreased in the somatotroph tumours. In another study, the type 1 IGF receptor was screened for mutations of the submembrane domain of the $\beta$ subunit of the IGF-R, which was found to be intact in 19 somatotroph adenomas, studied initially by SSCP and consequently confirmed by direct DNA sequencing (Greenman et al., 1995). Nevertheless, as IGF-I acts as a growth factor in 
Table 4 Frequency of the different GH-R polymorphisms

\begin{tabular}{lllll}
\hline Diagnosis & $601 \mathrm{bp}$ & $1673 \mathrm{bp}$ & exon 3 & $1516 \mathrm{bp}$ \\
\hline GH-R Reference sequence & $\mathrm{A}$ & $\mathrm{A}$ & present & $\mathrm{C}$ \\
Acromegaly & $\mathrm{G}+\mathrm{A}$ & $\mathrm{A}$ & hetero & $\mathrm{C}$ \\
Acromegaly & $\mathrm{G}+\mathrm{A}$ & $\mathrm{C}$ & present & $\mathrm{C}$ \\
Acromegaly & $\mathrm{G}$ & $\mathrm{C}$ & present & $\mathrm{C}$ \\
Acromegaly & $\mathrm{G}$ & $\mathrm{A}$ & present & $\mathrm{C}$ \\
Acromegaly & $\mathrm{A}$ & $\mathrm{A}$ & present & $\mathrm{C}$ \\
Acromegaly & $\mathrm{G}$ & $\mathrm{A}$ & present & $\mathrm{C}$ \\
Acromegaly & $\mathrm{G}$ & $\mathrm{C}$ & present & $\mathrm{C}$ \\
Acromegaly & $\mathrm{A}$ & $\mathrm{C}+\mathrm{A}$ & hetero & $\mathrm{C}$ \\
Acromegaly & $\mathrm{G}$ & $\mathrm{C}$ & present & $\mathrm{C}$ \\
Acromegaly & $\mathrm{G}$ & $\mathrm{C}+\mathrm{A}$ & present & $\mathrm{C}$ \\
Acromegaly & $\mathrm{G}$ & $\mathrm{C}+\mathrm{A}$ & present & $\mathrm{C}$ \\
Acromegaly & $\mathrm{A}$ & $\mathrm{A}$ & deleted & $\mathrm{C}$ \\
Acromegaly & $\mathrm{G}+\mathrm{A}$ & $\mathrm{C}+\mathrm{A}$ & hetero & $\mathrm{C}$ \\
Acromegaly & $\mathrm{A}$ & $\mathrm{A}$ & hetero & $\mathrm{C}+\mathrm{T}$ \\
Acromegaly & $\mathrm{G}$ & $\mathrm{C}+\mathrm{A}$ & present & $\mathrm{C}$ \\
Acromegaly & $\mathrm{G}+\mathrm{A}$ & $\mathrm{A}$ & hetero & $\mathrm{C}$ \\
Acromegaly & $\mathrm{A}$ & $\mathrm{A}$ & hetero & $\mathrm{C}$ \\
Acromegaly & $\mathrm{G}$ & $\mathrm{A}$ & deleted & $\mathrm{C}$ \\
NFPA & $\mathrm{G}$ & $\mathrm{C}+\mathrm{A}$ & present & $\mathrm{C}$ \\
NFPA & $\mathrm{A}$ & $\mathrm{A}$ & hetero & $\mathrm{C}$ \\
\hline
\end{tabular}

addition to any specific role it may have in terms of growth axis feedback, it is difficult to be certain that any changes seen in somatotroph tumours are pathogenetic.

It is difficult to establish from the present studies whether the changes in GH-R and IGF-R expression in somatotroph tumours, or indeed in other types of pituitary tumours, are a cause or a consequence of the tumorous state. In the rat, GH appears to suppress the expression of the GH-R, at least in the hypothalamus (Bennett et al., 1995), so it is possible that the GH-R is directly suppressed by the elevated GH (and IGF-I) levels characteristic of acromegaly. However, in acromegaly, there appears to be resetting of the feedback pathway such that elevated levels of GH and IGF-I coexist but are still responsive to a change in feedback; administration of the GH-antagonist pegvisomant lowers IGF-I levels and causes an approximate doubling in circulating $\mathrm{GH}$ levels (van der Lely et al., 2001), similar to the increase in GH levels seen with pegvisomant in normal volunteers (Veldhuis et al., 2001). This may indicate that that the feedback is still operative but reset to a new setpoint, concomitant with the diminished expression of the GH-R and IGF-R. Further studies should help differentiate between these two explanations. In addition, the mechanism of the decreased expression is unknown, but may include epigenetic changes, such as gene methylation.

In summary, we have investigated the GH-R for somatic mutations in a series of somatotroph adenomas, and have excluded such mutations in the coding region as a significant causal factor in the majority of somatotroph adenomas. We also quantified the GH-R and type 1 IGF-R mRNA in a series of somatotroph tumours, and related the levels to normal pituitary and other types of pituitary adenoma. The GH-R appears to be significantly lowered in somatotroph adenomas compared to the normal pituitary, where somatotrophs are the predominant cell type. The levels of IGF-R are also lower in somatotroph tumours, compared to the normal pituitary. Our immunostaining data are compatible with the diminution in GH-R and IGF-R mRNA leading to decreased protein expression.

\section{Acknowledgements}

BK was supported by the Cancer Research Committee of St. Bartholomew's Hospital, MK by the Medical Research Council, and DGM by the Joint Research Board of St Bartholomew's Hospital.

We are most grateful to our clinical colleagues, Prof J.P. Monson, Dr. S.L. Chew and Dr. P. Jenkins, and consultant neurosurgeons Ms. F. Afsher and Mr. I. Sabin, for provision of clinical material.

\section{References}

Abe, H., Molitch, M.E., Van Wyk, J.J. \& Underwood, L.E. (1983) Human growth hormone and somatomedin $\mathrm{C}$ suppress the spontaneous release of growth hormone in unanesthetized rats. Endocrinology, 113, 13191324 .

Abrams, R.L., Grumbach, M.M. \& Kaplan, S.L. (1971) The effect of administration of human growth hormone on the plasma growth hormone, cortisol, glucose, and free fatty acid response to insulin: evidence for growth hormone autoregulation in man. Journal of Clinical Investigation, 50, 940-950.

Asa, S.L. \& Ezzat, S. (1998) The cytogenesis and pathogenesis of pituitary adenomas. Endocrine Reviews, 19, 798-827.

Asa, S.L., Coschigano, K.T., Bellush, L., Kopchick, J.J. \& Ezzat, S. (2000) Evidence for growth hormone $(\mathrm{GH})$ autoregulation in pituitary somatotrophs in $\mathrm{GH}$ antagonist-transgenic mice and $\mathrm{GH}$ receptordeficient mice. American Journal of Pathology, 156, 1009-1015.

Bach, M.A. \& Bondy, C.A. (1992) Anatomy of the pituitary insulin-like growth factor system. Endocrinology, 131, 2588-2594.

Barinaga, M., Yamonoto, G., Rivier, C., Vale, W., Evans, R. \& Rosenfeld, M.G. (1983) Transcriptional regulation of growth hormone gene expression by growth hormone-releasing factor. Nature, 306, 84-85.

Bennett, P.A., Levy, A., Sophokleous, S., Robinson, I.C. \& Lightman, S.L. (1995) Hypothalamic GH receptor gene expression in the rat: effects of altered GH status. Journal of Endocrinology, 147, 225-234.

Berelowitz, M., Szabo, M., Frohman, L.A., Firestone, S., Chu, L. \& Hintz, R.L. (1981) Somatomedin-C mediates growth hormone negative feedback by effects on both the hypothalamus and the pituitary. Science, 212, 1279-1281.

Billestrup, N., Swanson, L.W. \& Vale, W. (1986) Growth hormone-releasing factor stimulates proliferation of somatotrophs in vitro. Proceedings of the National Academy of Sciences of the USA, 83, 6854-6857.

Bowers, C.Y., Momany, F.A., Reynolds, G.A. \& Hong, A. (1984) On the in vitro and in vivo activity of a new synthetic hexapeptide that acts on the pituitary to specifically release growth hormone. Endocrinology, 114, 1537-1545.

Bustin, S.A. (2000) Absolute quantification of mRNA using real-time reverse transcription polymerase chain reaction assays. Journal of Molecular Endocrinology, 25, 169-193. 
Clark, R.G., Carlsson, L.M. \& Robinson, I.C. (1988) Growth hormone (GH) secretion in the conscious rat: negative feedback of GH on its own release. Journal of Endocrinology, 119, 201-209.

Edens, A. \& Talamantes, F. (1998) Alternative processing of growth hormone receptor transcripts. Endocrine Reviews, 19, 559-582.

Ezzat, S. (2001) The role of hormones, growth factors and their receptors in pituitary tumorigenesis. Brain Pathology, 11, 356-370.

Ezzat, S. \& Melmed, S. (1990) The role of growth factors in the pituitary. Journal of Endocrinological Investigation, 13, 691-698.

Ezzat, S., Zheng, L., Zhu, X.F., Wu, G.E. \& Asa, S.L. (2002) Targeted expression of a human pituitary tumor-derived isoform of FGF receptor-4 recapitulates pituitary tumorigenesis. Journal of Clinical Investigation, 109, 69-78.

Fagin, J.A., Brown, A. \& Melmed, S. (1988) Regulation of pituitary insulin-like growth factor-I messenger ribonucleic acid levels in rats harboring somatomammotropic tumors: implications for growth hormone autoregulation. Endocrinology, 122, 2204-2210.

Fagin, J.A., Fernandez-Mejia, C. \& Melmed, S. (1989) Pituitary insulinlike growth factor-I gene expression: regulation by triiodothyronine and growth hormone. Endocrinology, 125, 2385-2391.

Fraser, R.A. \& Harvey, S. (1992) Ubiquitous distribution of growth hormone receptors and/or binding proteins in adenohypophyseal tissue. Endocrinology, 130, 3593-3600.

Goodyer, C.G., De Stephano, L., Lai, W.H., Guyda, H.J. \& Posner, B.I. (1984) Characterization of insulin-like growth factor receptors in rat anterior pituitary, hypothalamus, and brain. Endocrinology, 114, 11871195.

Greenman, Y., Prager, D. \& Melmed, S. (1995) The IGF-I receptor submembrane domain is intact in GH-secreting pituitary tumours. Clinical Endocrinology, 42, 169-172.

Hagen, T.C., Lawrence, A.M. \& Kirsteins, L. (1972) Autoregulation of growth hormone secretion in normal subjects. Metabolism, 21, 603-610.

Harris, P.E. (1996) Gs protein mutations and the pathogenesis and function of pituitary tumors. Metabolism, 45, 120-122.

Harvey, S. \& Fraser, R.A. (1992) Expression and translation of the growth hormone-receptor gene in the guinea-pig. Journal of Endocrinology, 133, 357-362.

Harvey, S., Baumbach, W.R., Sadeghi, H. \& Sanders, E.J. (1993) Ultrastructural colocalization of growth hormone binding protein and pituitary hormones in adenohypophyseal cells of the rat. Endocrinology, 133, 1125-1130.

Hayward, B.E., Barlier, A., Korbonits, M., Grossman, A.B., Jacquet, P., Enjalbert, A. \& Bonthron, D.T. (2001) Imprinting of the G (s) alpha gene GNAS1 in the pathogenesis of acromegaly. Journal of Clinical Investigation, 107, R31-R36.

Hosoda, H., Kojima, M., Matsuo, H. \& Kangawa, K. (2000) Purification and characterization of rat des-Gln14-Ghrelin, a second endogenous ligand for the growth hormone secretagogue receptor. Journal of Biology Chemistry, 275, 21995-22000.

Hull, K.L., Fraser, R.A. \& Harvey, S. (1992) Expression of the growth hormone receptor gene in chicken pituitary glands. Journal of Endocrinology, 135, 459-468.

Jaffe, C.A., Pan, W., Brown, M.B., DeMott-Friberg, R. \& Barkan, A.L. (2001) Regulation of GH secretion in acromegaly: reproducibility of daily GH profiles and attenuated negative feedback by IGF-I. Journal of Clinical Endocrinology and Metabolism, 86, 4364-4370.

Kaltsas, G.A., Kola, B., Borboli, N., Morris, D.G., Gueorguiev, M., Swords, F.M., Czirjak, S., Kirschner, L.S., Stratakis, C.A., Korbonits, M. \& Grossman, A.B. (2002) Sequence analysis of the PRKAR1A gene in sporadic somatotroph and other pituitary tumours. Clinical Endocrinology, 57, 443-448.
Kirschner, L.S., Sandrini, F., Monbo, J., Lin, J.P., Carney, J.A. \& Stratakis, C.A. (2000) Genetic heterogeneity and spectrum of mutations of the PRKAR1A gene in patients with the carney complex. Human Molecular Genetics, 9, 3037-3046.

Kojima, M., Hosoda, H., Date, Y., Nakazato, M., Matsuo, H. \& Kangawa, K. (1999) Ghrelin is a growth-hormone-releasing acylated peptide from stomach. Nature, 402, 656-660.

Korbonits, M., Chitnis, M.M., Norman, D., Rosenfelder, N., Suliman, M., Jones, T.H., Noonan, K., Fabbri, A., Besser, G.M., Burrin, J.M. \& Grossman, A.B. (2001) The release of leptin and its effect on hormone release from human pituitary adenomas. Clinical Endocrinology, 54, 781-789.

Korbonits, M., Chahal, H.S., Kaltsas, G., Jordan, S., Urmanova, Y., Khalimova, Z., Harris, P.E., Claret, F.X. \& Grossman, A.B. (2002) Expression of phosphorylated $\mathrm{p} 27^{\text {Kipl } 1}$ protein and Jab1 (Jun activation domain-binding protein 1) in human pituitary tumors. Journal of Clinical Endocrinology and Metabolism, 87, 2635-2643.

Lamberts, S.W. (1988) The role of somatostatin in the regulation of anterior pituitary hormone secretion and the use of its analogs in the treatment of human pituitary tumors. Endocrine Reviews, 9, 417-436.

Landis, C.A., Masters, S.B., Spada, A., Pace, A.M., Bourne, H.R. \& Vallar, L. (1989) GTPase inhibiting mutations activate the alpha chain of Gs and stimulate adenylyl cyclase in human pituitary tumours. Nature, 340, 692-696.

Lanzi, R. \& Tannenbaum, G.S. (1992) Time course and mechanism of growth hormone's negative feedback effect on its own spontaneous release. Endocrinology, 130, 780-788.

van der Lely, A.J., Hutson, R.K., Trainer, P.J., Besser, G.M., Barkan, A.L., Katznelson, L., Klibanski, A., Herman-Bonert, V., Melmed, S., Vance, M.L., Freda, P.U., Stewart, P.M., Friend, K.E., Clemmons, D.R., Johannsson, G., Stavrou, S., Cook, D.M., Phillips, L.S., Strasburger, C.J., Hackett, S., Zib, K.A., Davis, R.J., Scarlett, J.A. \& Thorner, M.O. (2001) Long-term treatment of acromegaly with pegvisomant, a growth hormone receptor antagonist. Lancet, 1754-1759.

Lidhar, K., Korbonits, M., Jordan, S., Khalimova, Z., Kaltsas, G., Lu, X., Clayton, R.N., Jenkins, P.J., Monson, J.P., Besser, G.M., Lowe, D.G. \& Grossman, A.B. (1999) Low expression of the cell cycle inhibitor p27Kip1 in normal corticotroph cells, corticotroph tumors, and malignant pituitary tumors. Journal of Clinical Endocrinology and Metabolism, 84, 3823-3830.

Mendelson, W.B., Jacobs, L.S. \& Gillin, J.C. (1983) Negative feedback suppression of sleep-related growth hormone secretion. Journal of Clinical Endocrinology and Metabolism, 56, 486-488.

Mertani, H.C. \& Morel, G. (1995) In situ gene expression of growth hormone $(\mathrm{GH})$ receptor and $\mathrm{GH}$ binding protein in adult male rat tissues. Molecular and Cellular Endocrinology, 109, 47-61.

Mertani, H.C., Waters, M.J., Jambou, R., Gossard, F. \& Morel, G. (1994) Growth hormone receptor binding protein in rat anterior pituitary. Neuroendocrinology, 59, 483-494.

Mertani, H.C., Pechoux, C., Garcia-Caballero, T., Waters, M.J. \& Morel, G. (1995) Cellular localization of the growth hormone receptor/binding protein in the human anterior pituitary gland. Journal of Clinical Endocrinology and Metabolism, 80, 3361-3367.

Nakamoto, J.M., Gertner, J.M., Press, C.M., Hintz, R.L., Rosenfeld, R.G. \& Genel, M. (1986) Suppression of the growth hormone (GH) response to clonidine and GH-releasing hormone by exogenous GH. Journal of Clinical Endocrinology and Metabolism, 62, 822826.

Otsuka, F., Tamiya, T., Yamauchi, T., Ogura, T., Ohmoto, T. \& Makino, H. (1999) Quantitative analysis of growth-related factors in human pituitary adenomas. Lowered insulin-like growth factor-I and its receptor 
mRNA in growth hormone-producing adenomas. Regulatory Peptides, 83, 31-38.

Petersenn, S., Heyens, M., Ludecke, D.K., Beil, F.U. \& Schulte, H.M. (2000) Absence of somatostatin receptor type 2 A mutations and gip oncogene in pituitary somatotroph adenomas. Clinical Endocrinology, 52, 35-42.

Petersenn, S., Aschmann, D., Ludecke, D.K., Beil, F.U. \& Schulte, H.M. (2001) Absence of mutations of the growth hormone secretagogue receptor in somatotrophic pituitary adenomas. Proceedings of the $83 \mathrm{rd}$ Annual Meeting of the Endocrine Society, Denver, CO, P1-95 (Abstract).

Pontiroli, A.E., Lanzi, R., Monti, L.D., Sandoli, E. \& Pozza, G. (1991) Growth hormone $(\mathrm{GH})$ autofeedback on $\mathrm{GH}$ response to GH-releasing hormone. Role of free fatty acids and somatostatin. Journal of Clinical Endocrinology and Metabolism, 72, 492-495.

Rosenthal, S.M., Silverman, B.L. \& Wehrenberg, W.B. (1991) Exogenous growth hormone inhibits bovine but not murine pituitary growth hormone secretion in vitro: evidence for a direct feedback of growth hormone on the pituitary. Neuroendocrinology, 53, 597-600.

Ross, R.J., Borges, F., Grossman, A., Smith, R., Ngahfoong, L., Rees, L.H., Savage, M.O. \& Besser, G.M. (1987a) Growth hormone pretreatment in man blocks the response to growth hormone-releasing hormone; evidence for a direct effect of growth hormone. Clinical Endocrinology, 26, 117-123.

Ross, R.J., Tsagarakis, S., Grossman, A., Nhagafoong, L., Touzel, R.J., Rees, L.H. \& Besser, G.M. (1987b) GH feedback occurs through modulation of hypothalamic somatostatin under cholinergic control: studies with pyridostigmine and GHRH. Clinical Endocrinology, 27, 727-733.

Salvatori, R., Thakker, R.V., Lopes, M.B., Fan, X., Eswara, J.R., Ellison, D., Lees, P., Harding, B., Yang, I. \& Levine, M.A. (2001) Absence of mutations in the growth hormone (GH)-releasing hormone receptor gene in $\mathrm{GH}-$ secreting pituitary adenomas. Clinical Endocrinology, 54, 301-307.

Tannenbaum, G.S. (1980) Evidence for autoregulation of growth hormone secretion via the central nervous system. Endocrinology, 107, 2117-2120.

Tannenbaum, G.S., Guyda, H.J. \& Posner, B.I. (1983) Insulin-like growth factors: a role in growth hormone negative feedback and body weight regulation via brain. Science, 220, 77-79.

Tricarico, C., Pinzani, P., Bianchi, S., Paglierani, M., Distante, V., Pazzagli, M., Bustin, S.A. \& Orlando, C. (2002) Quantitative real-time reverse transcription polymerase chain reaction: normalization to rRNA or single housekeeping genes is inappropriate for human tissue biopsies. Analytical Biochemistry, 309, 293-300.

Veldhuis, J.D., Bidlingmaier, M., Anderson, S.M., Wu, Z. \& Strasburger, C.J. (2001) Lowering total plasma insulin-like growth factor I concentrations by way of a novel, potent, and selective growth hormone $(\mathrm{GH})$ receptor antagonist, pegvisomant (B2036-peg), augments the amplitude of GH secretory bursts and elevates basal/nonpulsatile GH release in healthy women and men. Journal of Clinical Endocrinology Metabolism, 86, 3304-3310.

Willoughby, J.O., Menadue, M., Zeegers, P., Wise, P.H. \& Oliver, J.R. (1980) Effects of human growth hormone on the secretion of rat growth hormone. Journal of Endocrinology, 86, 165-169.

Yamashita, S. \& Melmed, S. (1987) Insulinlike growth factor I regulation of growth hormone gene transcription in primary rat pituitary cells. Journal of Clinical Investigation, 79, 449-452.

Yamashita, S., Weiss, M. \& Melmed, S. (1986) Insulin-like growth factor I regulates growth hormone secretion and messenger ribonucleic acid levels in human pituitary tumor cells. Journal of Clinical Endocrinology and Metabolism, 63, 730-735. 